\title{
Effects of prescribed forest burning on carabid beetles (Coleoptera: Carabidae): a case study in south-eastern Norway
}

\author{
Konstantin B. Gongalsky, Fred Midtgaard \& Hans J. Overgaard
}

Gongalsky, K. B., Midtgaard, F. \& Overgaard, H. J. 2006: Effects of prescribed forest burning on carabid beetles (Coleoptera: Carabidae): a case study in southeastern Norway. - Entomol. Fennica 17: 325-333.

The influence of prescribed burning on ground beetles was studied in a single 12ha stand that was partially clear-cut, selectively-cut and retained (= standing forest), and was compared to an unburned stand in 2002 in SE Norway. Thirty-two species were collected using Barber pitfall traps. Carabids were more numerous and more diverse in the burned area, compared to the unburned forest. Overall abundance was highest in the selectively-cut treatment, followed by the clear-cut and standing forest. Species diversity tended to increase in the sequence unburned forest - burned standing forest - burned selectively-cut - burned clearcut. Species composition differed little between the burned treatments. Pterostichus adstrictus, a species associated with open habitats and which frequently colonizes burned areas, was the most abundant species collected. It was most common in the burned area, particularly in the selectively-cut treatment. Our results suggest that burning of a single stand may support some carabid species, even endangered ones, although larger forest fires are probably more effective for conservation purposes.

K. B. Gongalsky, A. N. Severtsov Institute of Ecology and Evolution, Russian Academy of Sciences, Leninsky prospekt 33, Moscow, 119071, Russian Federation; E-mail:kocio@mail.ru

F. Midtgaard \& H. J. Overgaard, Department of Ecology and Natural Resource Management, Norwegian University of Life Sciences, P.O. Box 5003, N-1432 As, Norway

Received 20 December 2005, accepted 23 April 2006

\section{Introduction}

Wildfires are among the basic ecological factors that change habitats and initiate the succession of new forest communities (Zackrisson 1977, Niklasson \& Granström 2000, Ryan 2002). Burned areas are ephemeral habitats presenting a broad range of ecological niches that many insect species may exploit. Burned areas are attractive for insects because they provide an easily accessible source of nutrients, competition is low or absent, and temperature and moisture regimes are different and often more favourable than the surrounding unburned forests (Wikars 1992, McCullough et al. 1998).

Efficient fire suppression has been the rule in many countries during the 20th century, and has led to drastic decreases or even local extinctions of many pyrophilous insects (Gärdenfors 2000). To support these species, controlled burning of 
forests or logged-over areas (= prescribed burning) has become a part of modern forest management during the last decades. For example, in Sweden, $>1,000$ ha of forest are burned annually as a conservation measure (Granström 2001). These areas have often been partly logged before burning.

Recently, the importance of alternative harvesting methods and their effects on soil-living invertebrates has been widely discussed (e.g., Gardner \& Usher 1989, Atlegrim \& Sjöberg 1996, Koivula 2002). However, the effects of fire in alternatively-harvested stands on invertebrates have been much less studied. Although some logged areas are burned annually, there is very little evidence that such treatments have a conservation function (Wikars 1995a, Saint-Germain et al. 2005). Knowledge on the effects of burning harvested areas would help forest managers to optimize the positive effects of controlled burning on threatened species.

Several studies have described the composition of carabid beetle assemblages (Coleoptera: Carabidae) during forest successional cycles, under both natural and burned conditions (e.g., Holliday 1984, 1992, Muona \& Rutanen 1994, Butterfield 1997, Rainio \& Niemelä 2003). The influx of pyrophilous invaders may depend on the size of the burned area, the amount of burned wood left, competition by open-habitat generalist species that colonize the area between harvest and fire, and other, sometimes unknown, factors (Ahlgren 1974, Kolbe 1981, Wikars 1995a).

A field study was undertaken in SE Norway to investigate the insect assemblages of three burned forest treatments (clear-cut, selectivelycut, and standing forest) and one unburned forest habitat. In this paper, we report the results from the sampling of ground beetles. Results on other beetle groups, sampled using methods other than pitfall trapping and during subsequent post-fire years, will be presented in forth-coming reports.

\section{Material and methods}

\subsection{Study area}

The study area is situated in Gravberget, southeastern Norway, ca. $220 \mathrm{~km}$ north-east from Oslo $\left(60^{\circ} 58.8^{\prime} \mathrm{N}, 12^{\circ} 06.7^{\prime} \mathrm{E}\right)$. Mean annual temperature is ca. $+2.1^{\circ} \mathrm{C}$, with monthly averages ranging from $-10^{\circ} \mathrm{C}$ to $+14^{\circ} \mathrm{C}$. Mean annual precipitation is $795 \mathrm{~mm}$, with monthly averages ranging from 37 to $97 \mathrm{~mm}$ (measured at the nearest meteorological station in Trysil, http://met.no). The study area is about $450 \mathrm{~m}$ a.s.l. and consists of boreal conifer forests.

In May 2002, a prescribed burning of ca. 12 ha covered three habitat types: clear-cut (CC), selectively-cut (AC), and standing (= retained) forest (SF). A control site with unburned forest (UF) was situated about $100 \mathrm{~m}$ from the burned area. Both burned and unburned sites were predominantly covered with Norway spruce (Picea abies (L.) Karst.) forest on a hillside with a westerly aspect of approx. $15^{\circ}$ down to a small river. This set-up created a large variation in vegetation types, soil wetness and forest production potential within the study area.

On the top of the hill, the environment was dry with pine trees (Pinus sylvestris L.) and lichens (Cladonia spp.) dominating. Further down the hill, vegetation mainly consisted of Norway spruce and Calluna vulgaris (L.) Hull. Vaccinium shrubs were abundant on well-drained soils. Along the riverside, Norway spruce was growing on water-logged soils.

The northern end of the study area was a clearcut (CC; completely cleared of trees) with an exception of a strip of poor-quality-timber spruce trees left along the river margin for aquatic biotope protection purposes (approx. 5\% of area). The selectively-cut (AC) section was situated south and immediately adjacent to the $\mathrm{CC}$ site. The selective cutting was undertaken by harvesting approximately $90 \%$ of the trees, which represented a sufficiently large dimension to cover the expenses of the operation and leaving trees that would normally survive a low-intensity forest fire, such as large pines. Thus, approx. $10 \%$ of the trees were retained and evenly distributed throughout the area covered by the treatment. As in the CC, a strip of poor-quality-timber trees were left along the riverside. The third treatment, standing forest (SF), represented boreal conifer forest typical of the region, and was situated south of the AC site.

Moist weather preceded the prescribed forest fire, and heterogeneous soil conditions made the 
Table 1. Carabids collected during the summer of 2002 in Gravberget, SE Norway, in the four study plots: burned clear-cut (CC), burned selectively cut (AC), burned standing forest (SF), and unburned forest (UF). Group (= ecological groups): $\mathrm{H}=$ hygrophilous, $\mathrm{F}=$ closed forest, $\mathrm{O}=$ open-habitat species. No. spp. = observed number of species; Estim. no. spp. = Chao estimate of total number of species.

\begin{tabular}{|c|c|c|c|c|c|c|c|}
\hline & Species & Group & $\mathrm{CC}$ & $A C$ & SF & UF & Total \\
\hline 1 & Leistus terminatus Mellw. & $\mathrm{H}$ & - & - & - & 1 & 1 \\
\hline 2 & Notiophilus aquaticus L. & $\mathrm{H}$ & 1 & 5 & 4 & 1 & 11 \\
\hline 3 & N. biguttatus $\mathrm{F}$. & $\mathrm{F}$ & 26 & 50 & 17 & 2 & 95 \\
\hline 4 & N. germinyi Fauv. & $\mathrm{F}$ & 1 & 4 & 1 & 1 & 7 \\
\hline 5 & Carabus violaceus L. & $\mathrm{F}$ & 2 & 3 & 2 & - & 7 \\
\hline 6 & Cychrus caraboides L. & $\mathrm{F}$ & _- & 1 & - & - & 1 \\
\hline 7 & Cicindela campestris L. & 0 & 8 & 1 & - & - & 9 \\
\hline 8 & C. sylvatica L. & 0 & 2 & - & _- & _- & 2 \\
\hline 9 & Miscodera arctica Payk. & $\mathrm{F}$ & 2 & 1 & - & - & 3 \\
\hline 10 & Patrobus assimilis Chaud. & $\mathrm{F}$ & - & 3 & 3 & 4 & 10 \\
\hline 11 & $P$. atrorufus Stroem. & $\mathrm{H}$ & 1 & 1 & - & - & 2 \\
\hline 12 & Trechus rubens F. & $\mathrm{H}$ & _- & - & 1 & - & 1 \\
\hline 13 & Bembidion grapei Gyll. & 0 & 4 & 2 & - & - & 6 \\
\hline 14 & B. lampros Hbst. & 0 & 11 & 2 & - & - & 13 \\
\hline 15 & B. quadrimaculatus $\mathrm{L}$. & $\mathrm{H}$ & 1 & - & _- & _- & 1 \\
\hline 16 & Pterostichus adstrictus Esch. & $\mathrm{O}$ & 248 & 361 & 170 & 1 & 780 \\
\hline 17 & P. diligens Sturm & $\mathrm{H}$ & 1 & - & - & - & 1 \\
\hline 18 & P. oblongopunctatus $\mathrm{F}$. & $\mathrm{F}$ & 3 & - & - & - & 3 \\
\hline 19 & P. strenuus Panz. & $\mathrm{F}$ & 2 & 4 & 1 & - & 7 \\
\hline 20 & Calathus micropterus Duft. & $\mathrm{F}$ & $\overline{7}$ & 61 & 61 & 31 & 160 \\
\hline 21 & Agonum ericeti Panz. & $\mathrm{H}$ & 1 & - & - & - & 1 \\
\hline 22 & A. fuliginosum Panz. & $\mathrm{H}$ & - & - & 1 & _- & 1 \\
\hline 23 & Amara brunnea Gyll. & $\mathrm{F}$ & 1 & 1 & - & - & 2 \\
\hline 24 & A. communis Panz. & 0 & 1 & - & _ & _ & 1 \\
\hline 25 & A. Iunicollis Shiødte & $\mathrm{O}$ & 3 & - & 3 & - & 6 \\
\hline 26 & A. nigricornis Thoms. & 0 & - & 6 & 8 & _- & 14 \\
\hline 27 & A. plebeja Gyll. & 0 & _- & - & 1 & _- & 1 \\
\hline 28 & Harpalus fuliginosus Duft. & $\mathrm{O}$ & - & 1 & 1 & - & 2 \\
\hline 29 & H. quadripunctatus Dej. & $\mathrm{F}$ & 6 & 15 & 9 & _ & 30 \\
\hline 30 & Bradycellus caucasicus Chaud. & $\mathrm{O}$ & 1 & - & - & - & 1 \\
\hline 31 & Dicheirotrichus placidus Gyll. & $\mathrm{F}$ & 1 & - & - & - & 1 \\
\hline 32 & Cymindis vaporariorum $\mathrm{L}$. & $\mathrm{O}$ & - & 1 & 2 & - & 3 \\
\hline \multicolumn{3}{|c|}{ No. of individuals } & 334 & 523 & 285 & 41 & 1,183 \\
\hline \multicolumn{3}{|c|}{ No. spp. $\left(\mathrm{S}_{\text {ops }}\right)$} & 23 & 19 & 16 & 7 & 32 \\
\hline \multicolumn{3}{|c|}{ Estim. no. spp. (Chao Index; $S_{\text {ess }}$ ) } & 35.5 & 31.3 & 25.0 & 15.0 & \\
\hline \multicolumn{3}{|c|}{$S_{\text {obs }} / S_{\text {est }}$} & 0.65 & 0.61 & 0.64 & 0.47 & \\
\hline
\end{tabular}

burning very uneven, particularly in the forested part. Due to the high costs required to conduct this kind of experimental study, it was not possible to replicate the experimental set-up.

\subsection{Sampling}

Carabids were sampled in the three burned site types (CC, AC, and SF) and one unburned site
(UF) during the summer of 2002 using Barber pitfall traps (e.g., Baars 1979, Spence \& Niemelä 1994). At each site, two groups of pitfall traps were used to reduce sampling variation due to the heterogeneity of the area. The two trap groups were approx. 50-100 $\mathrm{m}$ apart at the uphill and downhill locations, respectively. Individual traps within each group were 3-5 m apart and set in a 20-m diameter circle. In each trap group, 10 plastic pitfall traps (mouth diameter $6 \mathrm{~cm}$, depth $8 \mathrm{~cm}$ ) 
were dug into the soil so that the rim of the cup was at the level of the soil surface.

The cups were partly filled with a 1:1 mixture of propylene glycol and water, with a drop of detergent to reduce surface tension. The traps were accompanied with transparent plastic roofs (set on wire "legs") to reduce the risk of flooding of the cups from rainfall (Phillips \& Cobb 2005). In total, 80 traps were used, and emptied in four occasions at 3-4 weeks intervals between 1 June and 4 September. Beetles were hand-sorted in the laboratory, and identified using the nomenclature by Kryzhanovskij et al. (1995). For analytical purposes, the collected insects from the four sampling periods were pooled to eliminate temporal variation.

\subsection{Statistical analyses}

The relative abundances of sampled beetle assemblages from the four sites were used in two analysis steps. First, the burned and unburned sites were compared; second, the three logging treatments within the burned area were compared. Differences in relative abundance of carabids among sites and treatments were tested using chi-square analysis.

Canonical correspondence analysis (CCA) with the four types of forest treatments (three logged, one un-harvested) as environmental dummy variables was applied to identify species associations with the treatments. Furthermore, the un-logged forest site was excluded from the analysis and thus only the 60 pitfalls from the burned sites were compared using correspondence analysis (CA). These ordinations were performed using CANOCO 4.0 (ter Braak \& Šmilauer 1998).

To evaluate the species diversity within each site, an abundance-based estimator of species richness $\left(\mathrm{S}_{\text {est }}\right)$ was calculated (Chao 1984):

$\mathrm{S}_{\mathrm{est}}=\mathrm{S}_{\mathrm{obs}}+\left(\mathrm{F}_{1}^{2} / 2 * \mathrm{~F}_{2}\right)$

where $\mathrm{S}_{\text {obs }}$ is the observed number of species, $\mathrm{F}_{1}$ is the number of singletons (species represented by a single individual) and $F_{2}$ is the number of doubletons (species represented by two individuals).

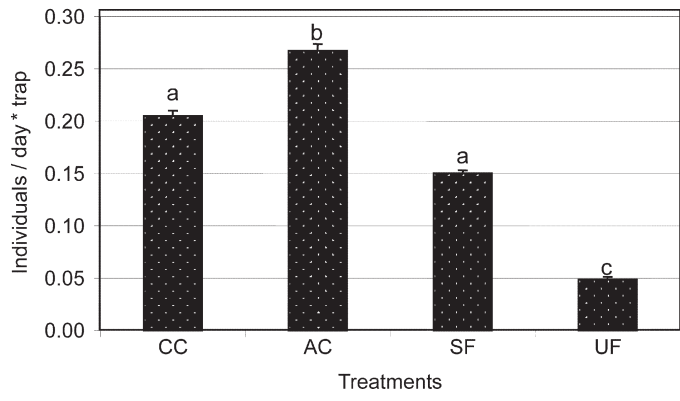

Fig. 1. Mean carabid catch in the four studied plots: burned clear cut (CC), burned selectively cut (AC), burned standing forest (SF), and unburned forest (UF) collected during the summer 2002 in Gravberget, SE Norway. Letters indicate statistically significant differences $(p<0.05)$.

Species were assigned to three ecological groups: hygrophilous, forest-associated and open-habitat species, according to their ecological associations (Lindroth 1992). Species accounting for $>7 \%$ of the catch within a given site were considered dominant.

\section{Results}

A total of 1,183 individuals from 32 species were collected. The three most numerous species were Pterostichus adstrictus, Calathus micropterus and Notiophilus biguttatus that altogether made up for almost $90 \%$ of the total carabid catch (Table 1). The mean carabid catch was $0.17( \pm 0.005$ $\mathrm{SE}$ ) individuals per trap per day (Fig. 1).

\subsection{Comparison of burned and unburned sites}

The average collection efficiency in the burned and unburned forest was $0.21( \pm 0.005 \mathrm{SE})$ and $0.05( \pm 0.003 \mathrm{SE})$ individuals per trap per day, respectively. Chi-square analysis showed significant differences between burned and unburned sites $\left(\chi^{2}=994.7, \mathrm{df}=1, p<0.001\right)$. Pterostichus adstrictus made up for $66 \%$ of the total catch and was the most abundant species in the burned sites. Only one specimen of $P$. adstrictus was found in the unburned forest. Only $3 \%$ of the total catch (seven species) were collected in the unburned forest (Table 1). Of these, C. micropterus was the 


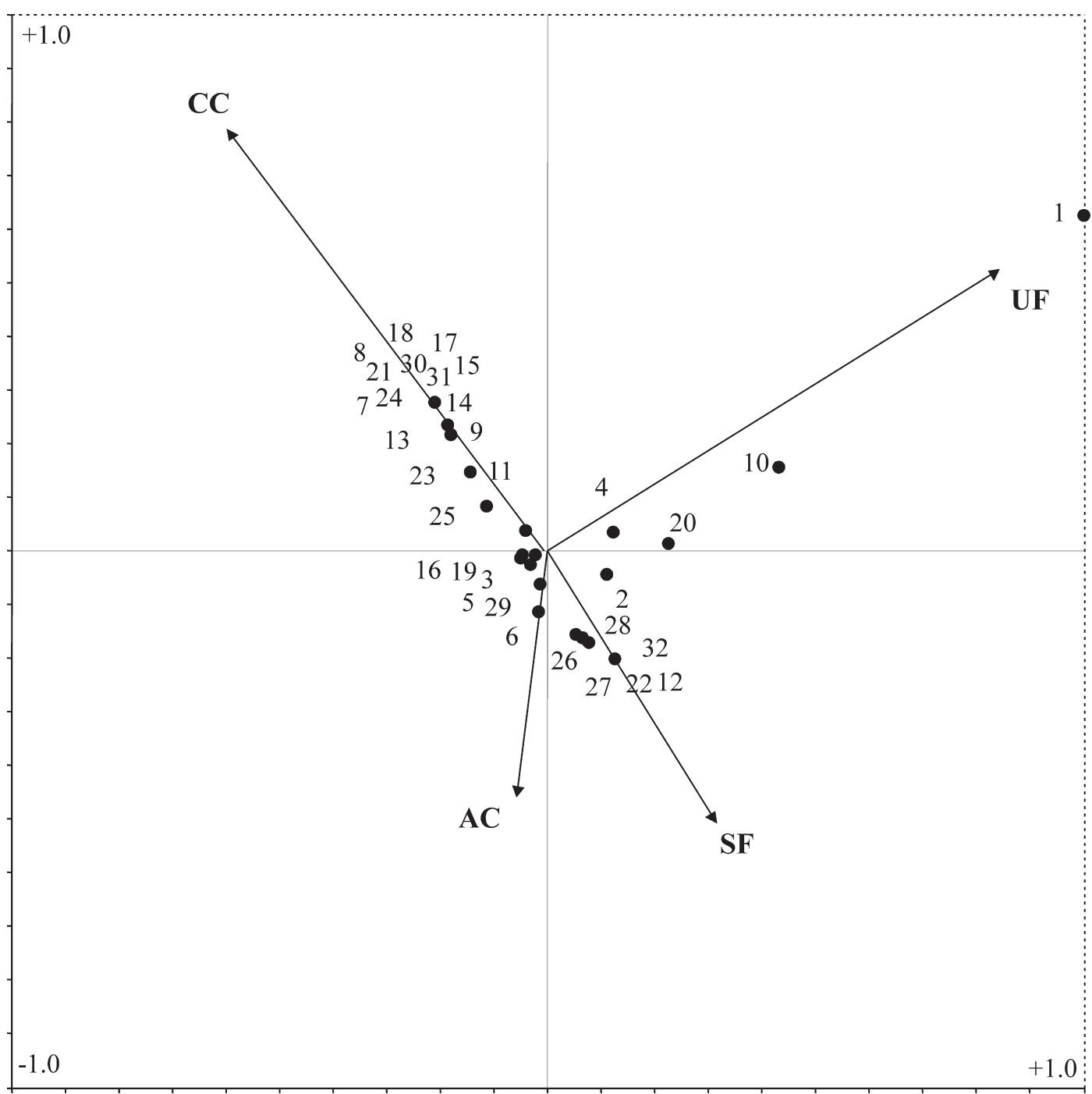

Fig. 2. Canonical correspondence analysis for the 80 pitfall traps with treatments as environmental dummy variables: burned clear-cut (CC), burned alternatively cut (AC), burned standing forest (SF), and unburned forest (UF). Numbers indicate species as shown in Table 1.

most abundant species. Leistus terminatus was the only species found exclusively in the unburned forest, but only one specimen was collected. The Chao index indicated that the burned sites hosted approx. two times higher species richness (25-35) than the unburned forest (UF; 15).

The CCA with treatment types as dummy variables revealed that some species were associated with certain types of treatments (Fig. 2). The first two axes in the CCA plot explained $93 \%$ of the total variability. For example, the analysis showed a relatively strong association between the forest site (UF) and Patrobus assimilis.

\subsection{Effects of burned forest treatments}

The beetle catch in the selectively-cut site (AC) was 0.27 ( $\pm 0.006 \mathrm{SE})$; in the clear-cut site (CC) $0.20( \pm 0.005 \mathrm{SE})$; and in the standing forest site (SF) $0.15( \pm 0.003 \mathrm{SE})$ individuals per trap per day. The average beetle catch for the three treatments differed significantly from the expected, 


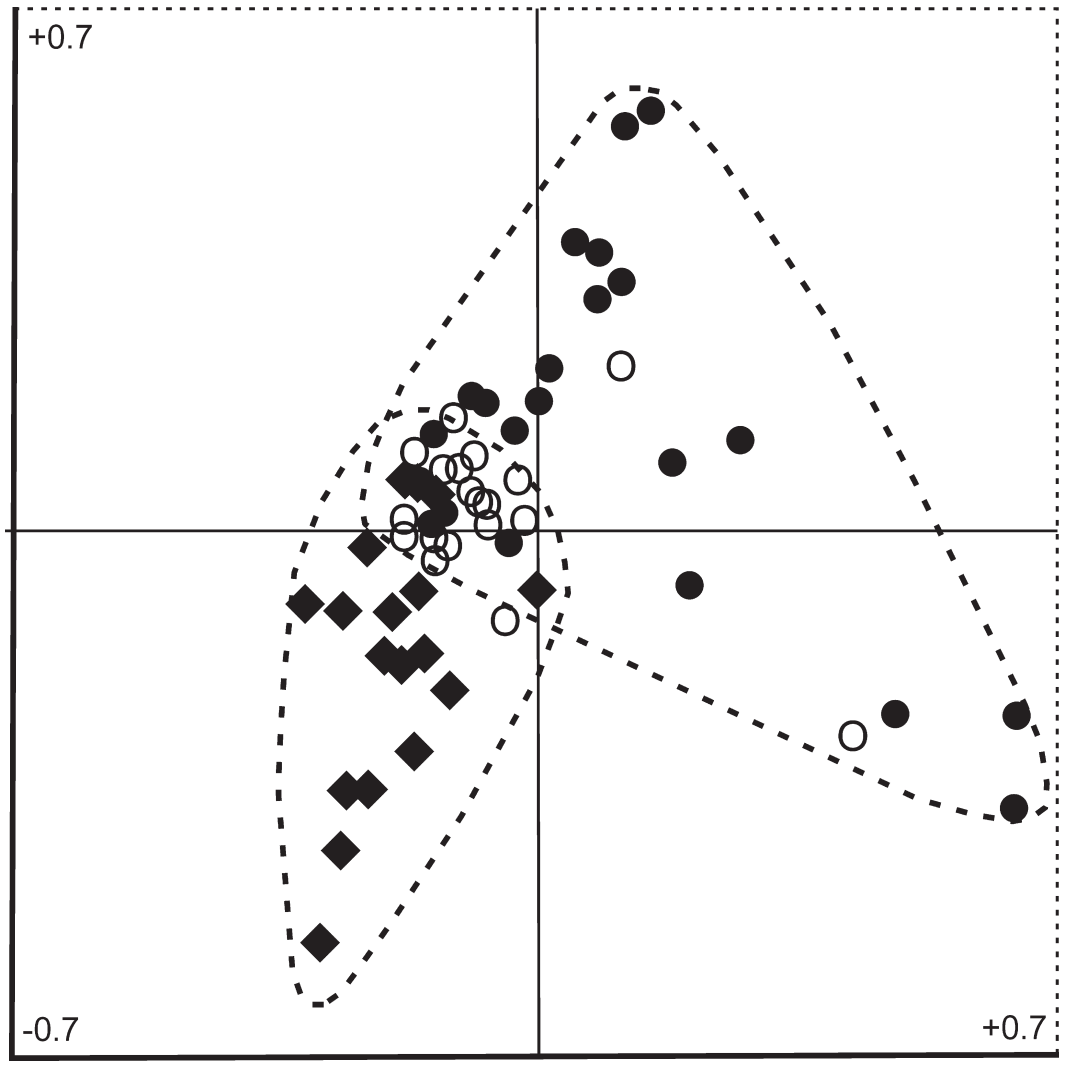

Fig. 3. Correspondence analysis for the 60 pitfall traps of the burned sites. Filled diamonds $=$ clear-cut (CC), open circles $=$ selective cut (AC), filled circles $=$ standing forest (SF). i.e. that collected numbers of beetles would be equal for the three treatments $\left(\chi^{2}=83.0, \mathrm{df}=2, p\right.$ $<0.001)$. Species richness was highest in the CC (23 species), followed by AC (19 species), and SF (16 species). The Chao index showed that the estimated numbers of species were higher than the observed number of species, indicating that continued sampling would produce more species than were actually collected.

The CCA showed several species being slightly associated with the CC treatment, and both open-habitat and forest specialists were collected in this site (Fig. 2, Table 1). The open-habitat specialists $P$. adstrictus, Bembidion lampros, Cicindela campestris and C. sylvatica were the most characteristic species in $\mathrm{CC}$, in addition to the forest species $N$. biguttatus that was also relatively abundant in the clear-cut. The CCA did not show clear associations between carabid species and $\mathrm{AC}$ or SF habitat types (Fig. 2).

The most abundant species in AC were P. adstrictus, $N$. biguttatus, and C. micropterus (Table 1). No particular species were more abun- dant in SF, compared to the other treatments.

Pterostichus adstrictus made up for $60 \%$ of the catch in SF, $69 \%$ in $\mathrm{AC}$, and $74 \%$ in $\mathrm{CC}$. Eleven additional open-habitat species ( $5 \%$ of total catch) were most abundantly caught in the CC site. The proportion of forest species was $27.6 \%$ of all specimens (12 species). Forest species decreased from $33 \%$ to $16 \%$ of treatment totals in the sequence SF-AC-CC. Eight hygrophilous species comprised less than $2 \%$ of the total catch.

Three species dominated the catch in CC, AC and SF habitats. In $\mathrm{CC}$, the dominant species were $P$. adstrictus and $N$. biguttatus. In AC, on the other hand, $P$. adstrictus, $N$. biguttatus and $C$. micropterus dominated, whereas in SF the most abundant species were $P$. adstrictus and C. micropterus. In UF, there was a single dominating species: C. micropterus.

The CA, including the 60 pitfall traps of "burned" treatments, separated CC from SF, while AC scores fell between the scores of the other two habitats (Fig. 3). The first two axes in the CA plot explained $41 \%$ of the total variability. 


\section{Discussion}

The carabid assemblages sampled in this study represented a typical set of species characteristic of boreal forests (e.g., Niemelä et al. 1988, Lindroth 1992). We found that carabids were more numerous and more diverse in the burned forest, compared to the untouched forest, as earlier shown by Wikars (1992), Gongalsky et al. (2003) and Saint-Germain et al. (2005). Prescribed burning should potentially attract fire specialists (Wikars 1995b), but we caught no true pyrophilous carabids, such as Sericoda quadripunctata Deg. or Pterostichus quadrifoveolatus Letz. The reasons for their absence might be related to the relatively small size of the burned area. Wikars (1995b) stated that the size of the burned forest may be an important factor in attracting pyrophilous species. Regarding conservation of pyrophilous carabids, burns should perhaps cover much more than the studied 12 ha, or several burns should be spread over larger geographical areas. Another contributing reason for the lack of pyrophilous carabids could be that these species in this particular region of Norway have become extremely rare or locally extinct. Thus, as south-eastern Norway has been exposed to few forest fires during the last decades, many pyrophilous carabids may already have a distribution too scattered to efficiently colonize a small fire.

The forest fire also apparently attracted other carabids, such as $P$. adstrictus, $N$. biguttatus, Harpalus quadripunctatus and B. lampros (or at least they were most abundant in burned sites). Such species can be attracted to the newly created habitat, but may not be obligatorily dependent on fires, because they also appear in unburned habitats (Wikars 1997). Wikars and Schimmel (2001) used the term "fire-favoured" for both obligatory and facultative pyrophilous insects and emphasized that distinguishing pyrophilous from firefavoured species can be difficult, particularly for soil-living species. Our material showed that these fire-favoured species were able to locate this fire, probably as a result of their high abundances in adjacent areas. Burned areas have the quality to support many insect species, often in high abundances, for several reasons. Perhaps the most notable factor is the ash- and burned-wood- covered black ground that is efficiently heated by the sun (Kimmins 1997) and is therefore attractive for thermophilous species (McCullough et al. 1998). Forested areas are generally wetter and cooler than open areas, which might negatively affect the abundance of many carabid species. Also, the capturing efficiency of pitfall traps in this type of forests might be reduced by the heterogeneity and rough structure of the soil surface caused by moss and lichen cover (e.g., Koivula et al. 2003). This could be the case in our unburned forest samples that had lower species richness than had the burned sites. The actual (observed) number of species $\left(\mathrm{S}_{\mathrm{obs}}\right)$ collected in UF was roughly two times lower than the estimated total number of species $\left(\mathrm{S}_{\text {est }}\right)$ (Table 1). Contrary to the UF habitat, the proportion of observed species richness and the estimated species richness in the burned sites was more than $60 \%$.

Pterostichus adstrictus was the most abundant species in our samples, with two-thirds of the total catch. This species often colonizes recently burned areas in large numbers and also becomes more abundant in the northern areas of Scandinavia than the more southerly distributed pyrophilous P. quadrifoveolatus (Wikars 1997). Furthermore, there were no red-listed species in our data set, and only one rare species was collected, viz. Bembidion grapei.

The highest carabid catch was found in the selectively-cut (AC) site, and the highest species diversity was observed in the clear-cut (CC) site. As discussed above, the higher capturing efficiency and richness estimates for the burned sites were probably due to the cleared and flat soil surface providing fewer possibilities for beetles to avoid traps. Differences between treatments, though, could potentially be caused by variations in micro-climate, habitat structure, food sources, or other unknown factors. However, the lack of replication in the present study suggests that these findings should be interpreted with caution. We cannot, for example, rule out the possibility of hidden environmental gradients (over the 12-ha area with the three burned treatments) that could partly be driving the results.

Prescribed burns of cut forests were originally planned as a measure against the decrease of abundance of pyrophilous species observed during the last decades in Scandinavia (Granström 
2001). Loss of species observed across Europe (Kotze \& O'Hara 2003) is thought to be partly reduced by prescribed fires, as they provide a broad range of ecological niches for species inhabiting forests, such as carabids. The relatively high abundance and large biodiversity reported in this study, as well as the presence of at least one rare species and several fire-favoured species, provide biological support for prescribed fires as a valuable conservation measure in boreal forests. We emphasize the importance of undertaking prescribed burning in environmentally heterogeneous areas, including a variety of habitats and forest management regimes, such as those present in this study. Such recommendations have also been made by other authors (e.g., Bohman et al. 2004). At present, prescribed burning in at least $5 \%$ of large land holdings in Sweden is recommended as a conservation measure for improved biodiversity by the Swedish Forest Stewardship Council (Swedish FSC 1998). Such measures should also be considered in Norway.

Acknowledgements. We are grateful to S. Ligaard, Vestby, Norway, for the identification of beetles. We are also grateful for the comments and suggestions from M. Koivula, University of Alberta, Canada, and two anonymous referees. The study was funded by the Research Council of Norway. KG acknowledges Young scientists support program by President of the Russian Federation (project MK1046.2005.4) and Foundation for Support of National Science.

\section{References}

Ahlgren, I. F. 1974: Effects of fire on soil organisms. - In: Kozlowski, T. T. \& Ahlgren, C. E. (eds), Fire and ecosystems: 67-72. Academic, New York.

Atlegrim, O. \& Sjöberg, K. 1996: Effects of clear-cutting and single-tree selection harvests on herbivorous insect larvae feeding on bilberry (Vaccinium myrtillus) in uneven-aged boreal Picea abies forests. - Forest Ecology and Management 87: 139-148.

Baars, M. A., 1979. Catches in pitfall traps in relation to mean densities of carabid beetles. - Oecologia 41: 25-46.

Bohman, P., Wikars, L.-O. \& Rydkvist, T. 2004: Inventering av tallkapuschongbaggar i södra Norrland. [Inventory of Stephanopachys linearis and Stephanopachys substriatus in Southern Norrland, Sweden]. Länsstyrelsen i Västernorrlands län, Härnösand, Sweden. 42 pp. [In Swedish.]

Butterfield, J. 1997: Carabid community succession dur- ing the forestry cycle in conifer plantations. - Ecography 20: 614-625.

Chao, A. 1984: Non-parametric estimation of the number of classes in a population. - Scandinavian Journal of Statistics 11: 265-270.

Gärdenfors, U. (ed.) 2000: Rödlistade arter i Sverige 2000. [Red-listed species in Sweden 2000] — ArtDatabanken, SLU, Uppsala, Sweden. 397 pp. [In Swedish.]

Gardner, S. M. \& Usher, M.B., 1989: Insect abundance on burned and cut upland Calluna heath. - The Entomologist 108: 147-157.

Gongalsky, K. B., Wikars, L.-O. \& Persson, T. 2003: Dynamics of pyrophilous carabids in a burned pine forest in Central Sweden. - Baltic Journal of Coleopterology 3: 107-111.

Granström, A. 2001: Fire management for biodiversity in the European boreal forest. - Scandinavian Journal of Forest Research, Suppl. 3: 62-69.

Holliday, N. J. 1984: Carabid beetles (Coleoptera: Carabidae) from a burned spruce forest (Picea spp.). - Canadian Entomologist 116: 919-922.

Holliday, N. J. 1992: The carabid fauna (Coleoptera: Carabidae) during postfire regeneration of boreal forest: properties and dynamics of species assemblages. Canadian Journal of Zoology 70: 440-452.

Kimmins, J. P. 1997: Forest ecology: a foundation for sustainable management. — N. J. Prentice Hall. 596 pp.

Koivula, M. 2002: Alternative harvesting methods and boreal carabid beetles (Coleoptera, Carabidae). - Forest Ecology and Management 167: 103-121.

Koivula, M., Kotze, D. J., Hiisivuori, L., Rita, H. 2002: Pitfall trap efficiency: do trap size, collecting fluid and vegetation structure matter? - Entomologica Fennica 14: $1-14$.

Kolbe, W. 1981: Die Auswirkungen eines Waldbrandes auf die Coleopteren-Fauna in Kieferforsten im Raum Brüggen. — Jahrsb. Naturwiss. Ver. Wupp. 34: 23-36.

Kotze, D. J. \& O'Hara, R. B. 2003: Species decline - but why? Explanations of carabid beetle (Coleoptera, Carabidae) declines in Europe. - Oecologia 135: 138148.

Kryzhanovskij, O. L., Belousov, I. A., Kabak, I. I., Kataev, B. M., Makarov, K. V. \& Shilenkov, V. G. 1995: A checklist of the ground beetles of Russia and adjacent lands (Insecta, Coleoptera, Carabidae). - Pensoft Publishers, Sofia-Moscow. 272 pp.

Lindroth, C. H. 1992: Ground beetles (Carabidae) of Fennoscandia. A zoogeograpic study. P. I. Specific knowledge regarding species. - Intercept, Andover. 630 pp.

McCullough, D. G., Werner R. A. \& Neumann D. 1998: Fire and insects in northern and boreal forest ecosystems of North America. - Annual Review in Entomology 43: 107-127.

Muona, J. \& Rutanen, I. 1994: The short-term impact of fire on the beetle fauna in boreal coniferous forest. Annales Zoologici Fennici 31: 109-121.

Niemelä, J., Haila, Y., Halme, E., Lahti, T., Pajunen, T. \& Punttila, P. 1988: The distribution of carabid beetles in fragments of old coniferous taiga and adjacent man- 
aged forest. - Annales Zoologici Fennici 25: 107 119.

Niklasson, M. \& Granström, A. 2000: Numbers and sizes of fires: long-term spatially explicit fire history in a Swedish boreal landscape. — Ecology 81: 1484 1499.

Phillips, I. D. \& Cobb, T. P. 2005: Effects of habitat structure and lid transparency on pitfall catches. - Environmental Entomology 34: 875-882.

Rainio, J. \& Niemelä, J. 2003: Ground beetles (Coleoptera: Carabidae) as bioindicators. - Biodiversity and Conservation 12: 487-506.

Ryan, K. C. 2002: Dynamic interactions between forest structure and fire behavior in boreal ecosystems. Silva Fennica 36: 13-39.

Saint-Germain, M., Larrivée, M., Drapeau, P., Fahrig, L. \& Buddle, C. M. 2005: Short-term response of ground beetles (Coleoptera: Carabidae) to fire and logging in a spruce-dominated boreal landscape. - Forest Ecology and Management 112: 118-126.

Spence, J. R. \& Niemelä, J. K., 1994: Sampling carabid assemblages with pitfall traps - the madness and the method. - Canadian Entomologist 126: 881-894.

Swedish FSC 1998: Standard for Forest Certification. -
Swedish Forest Stewardship Council. 43 pp. Available at http://www.fsc-sweden.org.

ter Braak, C. J. F. \& Šmilauer, P. 1998: CANOCO 4.0 Reference Manual and User's Guide to CANOCO for Windows. Software for Canonical Community Ordination. - Centre of Biometry, Wageningen.

Wikars, L.-O. 1992: Skogsbränder och insekter. [Forest fires and insects.] — Entomologisk Tidskrift 113: 111. [In Swedish.]

Wikars, L.-O. 1995a: Clear-cutting before burning prevents establishment of fire-adapted Agonum quadripunctatum (Coleoptera, Carabidae). - Annales Zoologici Fennici 32: 375-384.

Wikars, L.-O. 1995b: Brandinsekter i Orsa Finnmark: biologi, utbredning och artsbevarande. [Pyrophilous insects in Orsa Finnmark: biology, distribution, and conservation.] - Entomologisk Tidskrift 118: 155169. [In Swedish.]

Wikars. L.-O. \& Schimmel, J. 2001: Immediate effects of fire-severity on soil invertebrates in cut and uncut pine forests. - Forest Ecology and Management 141: 189_ 200.

Zackrisson, O. 1977: Influence of forest fires on the North Swedish boreal forest. — Oikos 29: 22-32. 